\title{
Antioxidant, nutritional and physicochemical quality of yoghurt produced from milk- based fermentation mix enhanced with food spices
}

Ogunyemi OM ( $\nabla$ omogunyemi1@gmail.com )

Salem University, Nigeria https://orcid.org/0000-0002-9956-3860

Gyebi GA

Bingham University

Shaibu Raheemat

Salem University, Nigeria

Fabusiwa MM

Salem University, Nigeria

Olaiya COO

University of Ibadan

\section{Research Article}

Keywords: spices, functional foods, antioxidants, sensory quality, Yoghurt

Posted Date: March 24th, 2021

DOl: https://doi.org/10.21203/rs.3.rs-352899/v1

License: (9) This work is licensed under a Creative Commons Attribution 4.0 International License.

Read Full License 


\section{Abstract}

Utilization of natural additives, which could meet the growing need for 'clean label' and value addition with respect to diseases prevention and health promotion in humans, is a current interest in the yoghurt industry. In this study, yoghurt recipes derived from standard milk -based fermentation mix enhanced with African black pepper (ABP), Turmeric, or Cloves extracts were evaluated for antioxidant, nutritional and physico-chemical quality. Each fermentation mix was pasteurized; inoculated with $0.5 \%$ industrial starter culture containing Streptococcus thermophillus and Lactobacillus delbrueckii subsp. Bulgaricus (1:1); and then allowed to ferment in fermentation tank for 9 hours at $40^{\circ} \mathrm{C}$. The results revealed that, cloveenriched yoghurt recipe exhibit the strongest antioxidant capacity as indicated by significant increase ( $p<$ 0.05) in total phenolics, total flavonoids, Total Antioxidant Capacity (TAC), DPPH radical scavenging activity, nitric oxide radical scavenging activity, Ferric ion reducing power (FRAP), and inhibition of lipid peroxidation but also reduced apparent viscosity and organoleptic properties. Similarly, ABP increased the antioxidant characteristics, with increased protein content and gel viscosity. Turmeric extracts significantly increased $(p<0.05)$ the calcium content and reduced syneresis. In conclusion, fermentation

of milk-based mix containing ABP extract resulted in yoghurt which combines improved antioxidant characteristics with increased protein and enhanced techno-functionality.

\section{Introduction}

Yoghurt is globally regarded as a functional food which combines unique nutritional values with promotion of gut health, heart functions, and natural immune defense in humans (Hashemi Gahruie et al., 2015; Caleja et al., 2016; Tavakoli et al., 2019). During fermentation of milk, lactic acid bacteria (LAB) utilize lactose and nitrogenous compounds leading to production of extracellular lactic acid and various other primary metabolites that provoke acidification of the medium. This causes several chemical changes which include decrease of $\mathrm{pH}$, increased nutrient bioavailability, formation of flavour compounds, coagulation of proteins, and the subsequent gel formation (Tamang et al., 2016; BrücknerGühmann et al., 2019). In the acidic medium, the net negative charge on casein micelles decreases, and thereby reduces electrostatic repulsion between charged groups causing coagulation and destabilization of the casein micelles and the conversion of the fluid milk into a viscoelastic gel (Brückner-Gühmann et al., 2019). These changes greatly influence the physicochemical characteristics and consumers' acceptability of yoghurt. While the texture components of yoghurt can be maintained and improved by optimizing the production process, the flavour, shelf-life and health benefits can be modified or enhanced by utilization of additives (Jaworska et al., 2005; Brückner-Gühmann et al., 2019).

A current interest in the yoghurt industry is utilization of natural additives towards developing new products which do not only cater for consumers' expectations regarding nutritional value and technofunctionality, but also meets the growing need for 'clean label' and value addition with respect to antioxidant potentials, diseases prevention and health promotion in humans. In this direction, herbal yoghurts, which are enhanced with Lycium barbarum extract (Baba et al., 2014), tea extracts (Muniandy et al., 2016), and mangosteen rind extract (Wibawanti et al., 2018) have been reported earlier. Antioxidant 
components of foods play a significant role in disease prevention and maintenance of health and wellbeing. They help to deactivate free radicals which can cause cells and tissue damages leading to various diseases of the modern human. Epidemiological studies have shown that antioxidants can prevent development of degenerative diseases such as cancer, coronary heart diseases, obesity, type 2 diabetes, hypertension, premature aging and inflammatory diseases (Senadeera et al., 2018). Besides, antioxidant compounds may enhance protection against lipid peroxidation, and peroxidability of yoghurt; thereby improving the shelf-life of the fermented product. Antioxidant capacity assays of food substances are useful in measuring the overall antioxidant activity due to the contents of the antioxidant compounds in the food matrix. Flavonoids constitute a large group of polyphenolic phytochemicals with antioxidant properties which are overwhelmingly exerted through direct free radical scavenging as reducing agents, hydrogen donors and singlet oxygen quenchers (Beckman, 2000). Flavonoids also exhibit antioxidant properties through chelating with transition metals, primarily $\mathrm{Fe}$ (II), $\mathrm{Fe}$ (III) and $\mathrm{Cu}$ (II), which participate in reactions generating free radicals in biological system. Interestingly, the metalflavonoid chelates formed are even more potent free radical scavengers than the parent flavonoids and play a prominent role in protection against oxidative stress (Dusan and Vesna, 2007; Cherrak et al., 2016). These antioxidant compounds are of interest in the food industry and human nutrition because of their attractive colour, stability in high acid foods and antioxidant power (Panche et al., 2016).

Food spices have multifarious roles such as antioxidant, medicinal, food flavouring, and preservative functions (Olaiya et al., 2013; Kapadiya et al., 2016; Gyebi et al., 2019). Our preliminary assessment revealed that, addition of extracts from several spices to milk- based fermentation mix improved the antioxidant potentials of yoghurt in a concentration- dependent manner and also increased the consumer acceptability of the products (Ogunyemi et al., 2020). The current study focused on further evaluation of the antioxidant, nutritional, and physicochemical characteristics of yoghurt enriched with $4 \%$ extracts from African black pepper (ABP) (Piper guineense), Turmeric (Curcuma longa), and Cloves (Syzygium aromaticum L.).

\section{Materials And Methods}

\section{1 Preparation of spice extracts}

Spice extracts were prepared from African black pepper (ABP), turmeric and clove as reported previously (Ogunyemi et al., 2020). The spices were purchased from the International Market, Lokoja, Kogi State, Nigeria. They were washed several times with tap water (Portable water). Then, peeled, rewashed with tap water, sliced into small sizes of 2- 3 diameter thick and dried in a vacuum oven at $60-65^{\circ} \mathrm{C}$ for 72 hours. The dried spices were blended into powder using a kitchen blender. The powder obtained was extracted with water to obtain the spice extracts.

\subsection{Preparation of spiced yoghurt samples}

Commercial skimmed milk comprising $32 \%$ protein, $54 \%$ lactose, $0.5 \%$ milk fat and $9 \%$ minerals was procured from DANO milk, Nigeria. Industrial freeze-dried starter culture (YoFlex CHR Hansen Company, 
Denmark.) containing Streptococcus thermophillus and Lactobacillus delbrueckii subsp. bulgaricus (1:1) was purchased. The samples of yoghurt were produced according to International Standard of yoghurt as described by Guler and Mutlu (2005). Here $400 \mathrm{~g}$ of skimmed powdered milk (comprising $32 \%$ protein, $54 \%$ lactose, $0.5 \%$ milk fat and $9 \%$ minerals) was reconstituted with water and heated to $80^{\circ} \mathrm{C}$ for 15 minutes for pasteurization, and then allowed to cool to $42-45^{\circ} \mathrm{C}$ before inoculation with starter culture. The milk mixture was divided into four portions, plain yoghurt, ABP-flavoured, turmeric flavoured, and clove spiced. They were incubated at $40^{\circ} \mathrm{C}$ and the fermentation process was monitored for 9 hours via production of lactic acid and $\mathrm{pH}$ value until a $\mathrm{pH}$ of about 4.9 was attained as reported in previous studies (Ogunyemi et al., 2020). The yoghurt samples were then packed and stored at $4^{\circ} \mathrm{C}$ until further analysis.

\subsection{Antioxidant analysis}

Total phenolic content in yoghurt samples was determined using the Folin Ciocalteu Reagent (FCR) method described previously by Singleton et al. (1999). The flavonoids were measured by aluminum chloride colorimetric assay as described by Zhishen et al. (1999). The DPPH• assay was carried out as described by Shirwaikar et al. (2006). Nitric oxide radical scavenging activity was determined according to the method reported by Johnson (1964). The ability of the samples to reduce oxidized iron was carried out as defined by Oyaizu (1986). Total Antioxidant Capacity (TAC) assay was carried out as described by Re et al. (1999). Inhibition of lipid peroxidation was carried out in accordance to the methods described by Ruberto et al. (2000) with slight modification.

\subsection{Chemical and Physicochemical Analysis}

Protein, ash, moisture content and total solids (TS) of the yoghurts were determined according to Latimer and Association of Official Analytical Chemists (2019). The pH-value and Total titratable acidity (TTA) were measured during fermentation. Titratable acidity in terms of lactic acid was measured according to Tomovska et al. (2016). The amount of $\mathrm{NaOH}$ used up was recorded and TTA was calculated as shown below.

Titratable acidity $=($ Titre value $\times 0.009) /($ Weight of sample $) \times 100(1)$

Apparent viscosity of the homogenized samples was measured using a Brookfield viscometer (Brookfield Programmable Rheometer, Model RVDV-III Ultra; Brookfield Engineering Laboratories, Stoughtm, MA, USA) with a spindle no. 4 and $10 \mathrm{rpm}$ rotation speed at $24^{\circ} \mathrm{C} \pm 1^{\circ} \mathrm{C}$. The values of apparent viscosity were recorded in centipoises (cP). Syneresis of the different yogurt samples was determined according to the methodology proposed by Dabija et al. (2018). $100 \mathrm{~mL}$ of each sample was placed in a funnel lined with Whatman filter paper number 1 . After $6 \mathrm{~h}$ of drainage, the volume of whey was measured and the susceptibility of syneresis was calculated thus:

Syneresis $=($ volume of whey collected after drainage $) /($ volume of yogurt sample $) \times 100$ 
The colour of yoghurt samples was determined by the Minolta Colour meter CR-410 model (Minolta Co., Osaka, Japan). The calibration of the meter was achieved using a white standard calibration plate ( $\mathrm{L}^{*}=$ $\left.92.95, a^{*}=-4.86, b^{*}-6.65\right)$. The CIE $L^{*}, a^{*}, b^{*}$ and $\Delta E$ values of the yoghurt were obtained directly from the meter. The hue angle $\left(\mathrm{h}^{\star}\right)$, and chroma $\left(\mathrm{C}^{\star}\right)$ were calculated.

\subsection{Sensory evaluation}

A total of 20 panelists from the Salem University Nigeria community, including university students and staff participated in the study. Panelist were chosen based on their willingness, availability and motivation. Sensory evaluation of plain and spice yoghurt was carried out to determine their organoleptic characteristics in terms of their colour, aroma, taste, texture and overall acceptance. A nine point hedonic scale, varying from dislike extremely (score 1) to like extremely (score 9) was used (Ogunyemi et al., 2020). To avoid bias, samples were coded so that the panelists could not identify them. The sample presentation order was randomized among and within assessors.

\subsection{Statistical analysis}

The data generated from the study were subjected to analyses using SAS 9.12 version and Graph Pad Prism. One -way analysis of variance (ANOVA) was used to detect the treatment effects. The means were separated by Duncan multiple range test (DMRT) and a probability value less than 0.05 was considered statistically significant

\section{Results}

\subsection{Fermentation of spiced yoghurt}

The fermentation process of the spiced yoghurt samples was monitored using decrease in $\mathrm{pH}$ and lactic acid accumulation as reported in figure 1.

Addition of the spice extracts had only slight effects on the fermentation process with respect to decreasing $\mathrm{pH}$ (figure 1a) as compared to that of the plain yoghurt (control). Similar results were recorded with respect to accumulation lactic (figure $1 \mathrm{~b}$ ). The $\mathrm{pH}$ of the final yoghurt samples ranged between 4.9 and 5.1 .

\subsection{Antioxidant potentials of the spiced yoghurts}

Figure 2 shows the in vitro antioxidant potentials of spiced yoghurt samples.

Although a small amount of phenolics $(9.78 \pm 0.57 \mathrm{mgGAE} / 100 \mathrm{ml})$ was detected in the plain yoghurt, this amount significantly increased $(\mathrm{p}<0.05)$ in all the spiced yoghurt samples. Addition of clove extracts gave 0.72 -fold increase in phenolic content as compared to the plain yoghurt (Figure 2a). Similar effects were also recorded for total flavonoid content in the yoghurt samples (Figure 2a). Clove gave the highest level of TAC and FRAP as observed in Figure $2 \mathrm{~b}$ and $2 \mathrm{c}$. The results also revealed that, most spice extracts 
significantly increased $(p<0.05)$ the inhibitory activity of yoghurt samples against DPPH radical. Addition of $4 \%$ Clove extract gave the highest inhibitory activity with up to 0.62 fold increases in DPPH scavenging activity as compared with the plain yoghurt. The nitric oxide radical scavenging activity of the yoghurt samples as shown in Figure $2 \mathrm{c}$ also shows a similar pattern with the DPPH scavenging assay. Both the plain yoghurt and spiced yoghurt also exhibit inhibition of lipid peroxidation and most of the spiced yoghurt had significant higher inhibition than the plain yoghurt (figure 2c).

\subsection{Effects of Spices on some nutrients in spiced yoghurt}

Table 1 shows the effects of incorporation of spice extracts on some nutrients of the yoghurt.

Table 1: Effects of $4 \%$ spice extracts on the contents of some nutrients in yoghurt

\begin{tabular}{cccc}
\hline Yoghurt Moisture (\%) Protein (\%) & Ash (\%) & Ca $(\mathrm{mg} / 100 \mathrm{~mL})$ & P $(\mathrm{mg} / 100 \mathrm{~mL})$ \\
\hline Control & $79.46 \pm 1.70^{\mathrm{a}} 2.54 \pm 0.12^{\mathrm{b}} 11.28 \pm 0.53^{\mathrm{ab}} 610.67 \pm 5.21^{\mathrm{ab}}$ & $2159.83 \pm 81.67^{\mathrm{a}}$ \\
ABP & $82.09 \pm 0.88^{\mathrm{a}} 3.67 \pm 0.19^{\mathrm{a}} 9.32 \pm 0.56^{\mathrm{b}}$ & $462.67 \pm 93.93^{\mathrm{b}}$ & $1549.67 \pm 57.76^{\mathrm{b}}$ \\
Turmeric $82.38 \pm 0.19^{\mathrm{a}} 3.80 \pm 0.23^{\mathrm{a}} 10.34 \pm 0.36^{\mathrm{ab}} 682.50 \pm 58.97^{\mathrm{a}}$ & $1215.10 \pm 98.84^{\mathrm{c}}$ \\
Clove $82.58 \pm 0.30^{\mathrm{a}} 3.96 \pm 0.16^{\mathrm{a}} 12.40 \pm 1.50^{\mathrm{a}} 635.83 \pm 32.73^{\mathrm{ab}} 1120.77 \pm 15.12^{\mathrm{c}}$ \\
\hline
\end{tabular}

Mean values $(\mathrm{N}=3)$ with different superscript in each column are significantly $(\mathrm{p}<0.05)$ different from one another. The means were separated by Duncan multiple range test (DMRT) and a probability value less than 0.05 was considered statistically significant $\mathrm{ABP}=$ African Black Pepper

While supplementation of yoghurt with the spice extracts had little or no effects on the moisture contents, all spice extracts significantly increased $(p<0.05)$ the protein content of the yoghurt samples as compared to the plain yoghurt. Clove extracts gave the highest increase in protein content with 0.61 fold significant increases, followed by turmeric and then ABP. On ash content, while addition of ABP and turmeric had little or no effect on the yoghurt samples, clove extract significantly increased the ash content. While addition of clove extracts had little or no effect on the calcium content, turmeric significantly increased $(p<0.05)$ the content of calcium in the yoghurt sample as compared with the plain yoghurt.

\subsection{Physico- chemical characteristics of spiced yoghurt samples}

The results shown in figure 4 revealed the effects of spice addition on the viscosity of the spiced yoghurt samples.

Addition of ABP increased the apparent viscosity as compared to the plain yoghurt and the other spiced yoghurt samples. Addition of turmeric and clove reduced the values of the apparent viscosity. 
Table 2: Effects of spice extracts on physicochemical properties of yoghurt

\begin{tabular}{lcccc}
\hline \multicolumn{1}{c}{ Parameters } & Control & ABP & Turmeric & Clove \\
\hline $\mathrm{pH}$ & $4.82 \pm 0.05^{\mathrm{a}}$ & $4.79 \pm 0.02^{\mathrm{a}}$ & $4.76 \pm 0.01^{\mathrm{a}}$ & $4.66 \pm 0.12^{\mathrm{a}}$ \\
Total Acid (\%) & $7.82 \pm 0.05^{\mathrm{a}}$ & $7.65 \pm 0.09^{\mathrm{a}}$ & $6.48 \pm 0.16^{\mathrm{b}}$ & $7.65 \pm 0.18^{\mathrm{a}}$ \\
\hline TSS (Brix) & $14.75 \pm 0.58^{\mathrm{a}}$ & $13.50 \pm 1.01^{\mathrm{ab}}$ & $12.83 \pm 0.36^{\mathrm{ab}}$ & $12.17 \pm 0.58^{\mathrm{b}}$ \\
\hline Syneresis & $64.00 \pm 1.15^{\mathrm{a}}$ & $65.33 \pm 0.67^{\mathrm{a}}$ & $53.33 \pm 3.53^{\mathrm{b}}$ & $59.33 \pm 1.76^{\mathrm{b}}$ \\
\hline WHC & $80.00 \pm 1.15^{\mathrm{a}}$ & $74.00 \pm 1.53^{\mathrm{a}}$ & $76.33 \pm 3.18^{\mathrm{a}}$ & $73.33 \pm 1.76^{\mathrm{a}}$ \\
\hline $\mathrm{L}^{*}$ & $70.54 \pm 0.11^{\mathrm{a}}$ & $66.62 \pm 2.58^{\mathrm{a}}$ & $66.90 \pm 4.71^{\mathrm{a}}$ & $66.61 \pm 6.24^{\mathrm{a}}$ \\
\hline $\mathrm{a}^{*}$ & $-13.37 \pm 0.09^{\mathrm{a}}$ & $-12.40 \pm 0.59^{\mathrm{a}}$ & $-13.44 \pm 0.99^{\mathrm{a}}$ & $-13.00 \pm 2.23^{\mathrm{a}}$ \\
\hline $\mathrm{b}^{*}$ & $11.25 \pm 0.16^{\mathrm{a}}$ & $11.18 \pm 0.56^{\mathrm{a}}$ & $13.61 \pm 1.22^{\mathrm{a}}$ & $12.76 \pm 1.14^{\mathrm{a}}$ \\
\hline $\mathrm{H}^{*}$ & $-0.69 \pm 0.00^{\mathrm{a}}$ & $-0.73 \pm 0.01^{\mathrm{a}}$ & $0.79 \pm 0.03^{\mathrm{a}}$ & $0.79 \pm 0.05^{\mathrm{a}}$ \\
\hline $\mathrm{C}^{*}$ & $17.46 \pm 0.18^{\mathrm{a}}$ & $16.69 \pm 0.80^{\mathrm{a}}$ & $19.15 \pm 1.48^{\mathrm{a}}$ & $18.27 \pm 2.31^{\mathrm{a}}$ \\
\hline$\Delta \mathrm{E}$ & $45.33 \pm 1.76^{\mathrm{a}}$ & $41.03 \pm 2.51^{\mathrm{a}}$ & $31.05 \pm 9.64^{\mathrm{a}}$ & $38.71 \pm 6.97^{\mathrm{a}}$ \\
\hline
\end{tabular}

Mean values $(\mathrm{N}=3)$ with different superscript in each column are significantly $(\mathrm{p}<0.05)$ different from one another. The means were separated by Duncan multiple range test (DMRT) and a probability value less than 0.05 was considered statistically significant Addition of both turmeric and clove extracts significantly reduced syneresis of the yoghurt samples by 0.45 fold and 0.48 fold respectively. Addition of spice extracts to yoghurt did not have significant effect on the colour characteristics of the yoghurt (Table 2). Results in table 2 revealed that enrichment of the milk-based fermentation mix with the spice extracts did not cause significant change to the colour characteristics of the yoghurt samples in terms of the degree of lightness $\left(L^{*}\right)$, red- green range $\left(a^{*}\right)$, yellow-blue range $\left(b^{\star}\right)$, chroma $\left(C^{\star}\right)$, hue angle $(h)$, and the total colour difference $(\Delta E)$ comparison to the control.

\subsection{Sensory Characteristics}

Consumer acceptability is a key factor in product development. Results of sensory profile analysis of the spiced yoghurts are summarized in figure 4.

\section{Discussion}

Enrichment of milk- based fermentation mix with fruits, food spices and medicinal herbs as additives presents a novel approach for developing functional yoghurts with improved nutritional, antioxidant, and therapeutic properties. Addition of the spice extracts used in this study had little or no effect on the 
fermentation process as monitored with decrease in $\mathrm{pH}$ and accumulation of lactic acid. The fermentation of the plain and spiced yoghurt may be said said to follow the general fermentation process (Figure 1) which occurs in three phases viz: the lag phase characterized by slow pH decrease, logarithmic phase with a rapid pH decrease and eventual decelerated acidification (Corrieu and Béal, 2016). This is generally accompanied with lactic acid accumulation and coagulation of milk beginning at $\mathrm{pH} 5.4$ and completing at pH 4.6 (Güner et al., 2007; Lee and Lucey, 2010).

The endogenous antioxidant potential exhibited by the plain yoghurt in this study may be due to substances such as peptides, free amino and fatty acids with antioxidant activities that are generated from the milk during fermentation as reported earlier by Tavakoli et al. (2019). Biochemical event such as proteolysis of milk proteins may yield amino acids with phenolic side chains such as tyrosine which react with the Folin-Ciocalteu reagent (Raikos et al., 2018). Also, metabolism of phenolic compounds by the lactic acid bacteria may be associated with flavonoid glycoside hydrolysis or C-ring cleavage and the release of simple phenolics such as phenolic acids (Muniandy et al., 2016). Enhancement of the antioxidant potentials of yoghurt samples with the spice extracts may be due to enrichment of the yoghurt with phenolic and flavonoid compounds as these spices are known as good sources of polyphenolic compounds (Kapadiya et al., 2016). Furthermore, some endogenous peptides may also be able to exert a marked synergistic effects with phenolic antioxidants from plant products (Citta et al., 2017). The influence of the spice extract on the antioxidant capacity of the yoghurt samples is consistent with earlier reports on supplementation of cow, buffalo, and goat milk yogurts with aqueous extracts of Zingiber officinale and Beta vulgaris (Srivastava et al., 2015). These authors reported that highest antioxidant activities with DPPH and FRAP methods were found in $2 \%$ ginger rhizome goat milk yoghurt and $2 \%$ beet root goat milk yoghurt followed by $2 \%$ ginger cow milk yoghurt. The lowest antioxidant activity was found in buffalo milk herbal yoghurt. Another study incorporated vegetable extracts (carrots, pumpkin, broccoli, and red sweet pepper) at $10 \%$ concentration, and ferric reducing antioxidant power (FRAP), and DPPH assays were used for anti-oxidant activity during the storage period of 14 days. Yogurt with broccoli, and red sweet pepper revealed higher DPPH free radical scavenging activity and FRAP (Najgebauer-Lejko and Sady, 2015). Yogurt was supplemented with fruit pulp of papaya and cactus pear using Lactobacillus bulgaricus and Streptococcus thermophiles as starter cultures, and total phenolic contents, ascorbic acid, and total antioxidant activity were analyzed. Yogurt added with papaya fruit pulp had higher total phenolic contents, antioxidant activity, and Vitamin C concentration (Khan et al., 2019).

The moisture content of the spiced yoghurt was maintained within the range of most yoghurt available in the market (80-86\%) (Ndife, 2014). Enrichment of the yoghurt samples with plant proteins from the spices might account for the improved protein content of the spiced yoghurt. It is known that, addition of plant proteins lead to the improvement of the quality of yogurt and an increase in its nutritional value (Dabija et al., 2018). Many researchers have successfully fortified yogurt with plant proteins (Akalin et al., 2012; Morell et al., 2015). Such fortification may have positive impacts on the textural and physical properties of yogurts such as yogurt firmness, viscosity and functional properties. The firming effect of different 
proteins addition in the formulation of yogurts could lead to a distinctive structure of the casein, with desirable effects on the textural characteristics of finished product (Dabija et al., 2018). On the other hand, for the consumer, the increase in the protein content improves the degree of satiety, especially beneficial for those who consume fermented dairy products for health reasons, certain diets, etc. (Dabija et al., 2018). The ash content is a reflection of the amount of minerals in a food material (Gemede et al., 2015). Calcium, which plays key roles in bone formation and mineralization, is highly required during growth, pregnancy, and lactation (Soetan et al., 2009; Gemede et al., 2015). This, therefore, means that the turmeric enriched yoghurt would be a beneficial drink for the children, pregnant and lactating mothers as well as the elderly whose calcium requirement is high.

Supplementation of yoghurt with ABP gave the highest viscosity as compared to the plain yoghurt and other spiced yoghurt samples. This is in contrast with the general believe that, addition of plant extracts decreases the consistency of the products owning to reduced water-binding capacity of proteins (Ramaswamy and Basak, 1992; El-Said et al., 2014). The improved viscosity may be due to contribution of protein (as reported in table 4) to the fermentation medium, leading to improvement of the technofunctionality of the product. This can be attributed to the positive impact of protein enrichment on the aggregation of casein network in yoghurts via electrostatic interaction, and on the resistance for the yoghurt matrix to flow. This study also shows that, addition of turmeric and clove extracts helped to reduce the syneresis of the spiced yoghurt. Tendency to syneresis gives information about the stability of the gel samples. The rate of syneresis in acidified milk gels like yoghurt is mainly determined by the microstructure of the protein network. If the water binding is not sufficient, whey will be expelled on the surface of the product during storage. During yogurt making process, the level of lactic acid becomes higher as fermentation goes on, and a series of cascade such as increase in acidity, dissociation of the carboxyl groups, ionization of serine phosphate and increase in the negative charge between casein micelles take place respectively. At this point, whey proteins are denatured and are more susceptible to association with casein and casein micelles. Additionally, during acidification, the denatured whey proteins, associated or not with casein micelles, aggregate. This results from the neutralization between calcium phosphate and the increasing negative charge and due to the presence of these attractive forces, repulsive charge is reduced and the casein micelles aggregate and eventually coagulate into a network of small chains, yoghurt coagulum and a visco-elastic gel (Brückner-Gühmann et al., 2019).

Enrichment of yoghurt with ABP increased the viscosity of yoghurt sample. This may have desirable effects on the eating quality of the spiced yoghurt. Spice did not have significant effects on the instrumental viscosity colour measurements. Thus, the colour attributes of the yoghurt samples were maintained. In addition, sensory evaluation revealed that, enrichment of fermentation mix with ABP gave the highest colour, aroma, taste, texture and overall acceptance score as compared to that of other spices but less that of the plain yoghurt. Colour is perceived as a measure of quality among consumers and could greatly influence the consumer's acceptability of food products. It is used to measure other quality attributes such as flavour, sensory, nutritional, and pigments, due to its simplicity and good correlation with other physicochemical properties. 


\section{Conclusion}

Yoghurt containing clove extracts showed the highest antioxidant potential and reduced rate of syneresis but also reduced viscosity and organoleptic properties. In the case of ABP, antioxidant characteristics, protein content and viscosity were enhanced with minimal effects on consumer acceptability. Effects of turmeric extracts include improved calcium content and reduced syneresis but reduced total solids. Overall, African black pepper showed remarkable desirable effects on the product as its addition to the milk-based fermentation mix resulted in yoghurt, which combines improved antioxidant characteristics with increased protein content, and viscosity. Therefore, enrichment of yoghurt with these food spices undoubtedly constitutes a good way for improving the nutritional value and health benefits of yoghurt. Such recipes may be considered for optimization and development towards producing new functional yoghurt.

\section{Declarations}

Funding: This research received no external funding

Acknowledgments: The technical support of Mr Onugwu Ernest of the Department of Biochemistry, Salem University, Nigeria and Miss Wura Subuloye of Department of Biochemistry, University of Ibadan is well acknowledged

Conflicts of Interest: The authors declare no conflict of interest.

Ethical approval - The procedure for the sensory evaluation of the food product was approved by the Salem University Research Ethics Committee (SUREC).

\section{Literature}

Akalin, A., Unal, G., Dinkci, N., Hayaloglu A. (2012): Microstructural, textural, and sensory characteristics of probiotic yogurts fortified with sodium calcium caseinate or whey protein concentrate. J Dairy Sci 95: 3617-3628.

Baba, A., Najarian A., Shori A., Lit W., Keng A. (2014): Viability of Lactic Acid Bacteria, Antioxidant Activity and In Vitro Inhibition of Angiotensin-I-Converting Enzyme of Lycium barbarum Yogurt. Arabian Journal for Science and Engineering 39: 5355-5362. doi: 10.1007/s13369-014-1127-2

Beckman C. (2000): Phenolic-storing cells: keys to programmed cell death and periderm formation in wilt disease resistance and in general defence responses in plants? Physiological and Molecular Plant Pathology 57: 101-110.

Brückner-Gühmann, M., Benthin, A., Drusch S. (2019): Enrichment of yoghurt with oat protein fractions: Structure formation, textural properties and sensory evaluation. Food Hydrocolloids 86: 146-153. 
Caleja, C., Barros, L., Antonio, A., Carocho, M., Oliveira, M., Ferreira, I. (2016): Fortification of yogurts with different antioxidant preservatives: A comparative study between natural and synthetic additives. Food Chem 210: 262-268.

Cherrak, S., Mokhtari-Soulimane, N., Berroukeche, F., Bensenane, B., Cherbonnel, A., Merzouk, H., Elhabiri M. (2016): In Vitro Antioxidant versus Metal lon Chelating Properties of Flavonoids: A Structure-Activity Investigation. PLOS ONE 11: e0165575-e0165575.

Citta, A., Folda, A., Scalcon, V., Scutari, G., Bindoli, A., Bellamio, M., Feller, E., Rigobello M. (2017): Oxidative changes in lipids, proteins, and antioxidants in yogurt during the shelf life. Food Science \& Nutrition 5: 1079-1087.

Corrieu G., Béal, C. (2016): Yogurt: The Product and its Manufacture. The Encyclopedia of Food and Health 5: 617-624. doi: 10.1016/B978-0-12-384947-2.00766-2

Dabija, A., Codina, G., Anca, G., Sanduleac, E., Lacramioara R. (2018): Effects of some vegetable proteins addition on yogurt quality. Scientific Study and Research: Chemistry and Chemical Engineering, Biotechnology, Food Industry 19: 181-192.

Dusan, M., Vesna, K. (2007): Investigation of metal-flavonoid chelates and the determination of flavonoids via metal-flavonoid complexing reactions. Journal of the Serbian Chemical Society 72: 921939. 10.2298/JSC0710921M

El-Said M., Haggag H., Fakhr El-Din H., Gad A., Farahat A. (2014): Antioxidant activities and physical properties of stirred yoghurt fortified with pomegranate peel extracts. Annals of Agricultural Sciences 59: 207-212.

Gemede, H., Haki, G., Beyene, F., Woldegiorgis, A., Rakshit S. (2015): Proximate, mineral, and antinutrient compositions of indigenous Okra (Abelmoschus esculentus) pod accessions: implications for mineral bioavailability. Food Science \& Nutrition 4: 223-233. 10.1002/fsn3.282

Güner, A., Ardic, M., Keles, A., Doğruer Y. (2007): Production of yogurt ice cream at different acidity. International Journal of Food Science \& Technology 42: 948-952. 10.1111/j.1365-2621.2006.01315.x

Guler A, Mutlu B (2005). The effect of different incubation, temperature on bacteria counts of bio-yoghurt made from ewe's milk. Int. J. Dairy Technol. 58:1784-1789.

Gyebi, G., Ocheje, J., Ogunyemi O. (2019): Molecular docking studies on bioactive compounds from clove (Syzygium Aromaticum) on metabolic regulators in cancer. Salem University Journal of Life Sciences 1: 1-18.

Hashemi Gahruie, H., Eskandari, M., Mesbahi, G., Hanifpour M. (2015): Scientific and technical aspects of yogurt fortification: A review. Food Science and Human Wellness 4: 1-8. 
Jaworska, D., Rak, C., Kolanowski, W., Swiderski F. (2005): Relative importance of texture properties in the sensory quality and acceptance of natural yoghurts. International Journal of Dairy Technology 58: 39-46. 10.1111/j.1471-0307.2005.00178.x

Johnson E. (1964): THE QUANTITATIVE ANALYSIS OF DRUGS. By D. C. Garratt. Journal of Pharmacy and Pharmacology 16: 772-772. 10.1111/j.2042-7158.1964.tb07408.x

Kapadiya, D., Dabhi, B., Aparnathi, K. (2016): Spices and Herbs as a Source of Natural Antioxidants for Food. International Journal of Current Microbiology and Applied Sciences 5: 280-288.

10.20546/ijcmas.2016.507.029

Khan, I., Bule, M., Ullah, R., Nadeem, M., Asif, S., Niaz, K. (2019): The antioxidant components of milk and their role in processing, ripening, and storage: Functional food. Vet World 12: 12-33.

10.14202/vetworld.2019.12-33

Latimer, G. Association of Official Analytical Chemists I. (2019): Official methods of analysis of AOAC International, Gaithersburg, Maryland: AOAC International.

Lee,W., Lucey, J. (2010): Formation and Physical Properties of Yogurt. Asian-Australasian Journal of Animal Sciences 23: 1127 - 1136. 10.5713/ajas.2010.r.05

Morell, P., Hernando, I., Llorca, E., Fiszman S. (2015): Yogurts with an increased protein content and physically modified starch: Rheological, structural, oral digestion and sensory properties related to enhanced satiating capacity. 70: 64-73. 10.1016/j.foodres.2015.01.024

Muniandy, P., Shori, A., Baba, A. (2016): Influence of green, white and black tea addition on the antioxidant activity of probiotic yogurt during refrigerated storage. Food Packaging and Shelf Life 8: 1-8. https://doi.org/10.1016/j.fpsl.2016.02.002

Najgebauer-Lejko, D., Sady, M. (2015): Estimation of the antioxidant activity of the commercially available fermented milks. Acta Scientiarum Polonorum, Technologia Alimentaria 14: 387-396.

10.17306/J.AFS.2015.4.38

Ndife, J. (2014): Production and Quality Assessment of Functional Yoghurt Enriched with Coconut. International Journal of Nutrition and Food Sciences 3: 545-550. 10.11648/j.ijnfs.20140306.19

Ogunyemi, O., Gyebi, G., Shaibu, O., Ozonwa, O., Olaiya C. (2020): Enhancement of antioxidant potential of yoghurt with natural additives: preliminary sensory and in vitro antioxidant analyses. Salem University Journal of Life Sciences 2: 1-17.

Olaiya, C., Choudhary, M., Ogunyemi, O., Nwauzoma, A. (2013): Nutraceuticals from Bitter Leaf (Vernonia amygdalina Del.) Protects against Cadmium Chloride induced Hypertension in Albino Rats. Nature and Science 11: 136-145. 
Oyaizu, M. (1986): Studies on products of browning reaction antioxidative activities of products of browning reaction prepared from glucosamine. Japanese Journal of Nutrition 44: 307-316.

Panche, A., Diwan, A., Chandra S. (2016): Flavonoids: an overview. Journal of nutritional science 5: e47e47. 10.1017/jns.2016.41

Raikos, V., Ni, H., Hayes, H., Ranawana V. (2018): Antioxidant Properties of a Yogurt Beverage Enriched with Salal (Gaultheria shallon) Berries and Blackcurrant (Ribes nigrum) Pomace during Cold Storage. Beverages 5 .

Ramaswamy, H., Basak S. (1992): Pectin and Raspberry Concentrate Effects on the Rheology of Stirred Commercial Yogurt. Journal of Food Science 57: 357-360. 10.1111/j.1365-2621.1992.tb05494.x

Re, R., Pellegrini, N., Proteggente, A., Pannala, A., Yang, M., Rice-Evans C. (1999): Antioxidant activity applying an improved ABTS radical cation decolorization assay. Free Radic Biol Med 26: 1231-1237.

Ruberto, G., Baratta, M., Deans, S., Dorman, H. (2000) Antioxidant and antimicrobial activity of Foeniculum vulgare and Crithmum maritimum essential oils. Planta Med 66: 687-693. 10.1055/s-20009773

Senadeera, S., Prasanna, P., Jayawardana, N., Gunasekara, D., Senadeera, P., Chandrasekara A. (2018): Antioxidant, physicochemical, microbiological, and sensory properties of probiotic yoghurt incorporated with various Annona species pulp. Heliyon 4: e00955. https://doi.org/10.1016/j.heliyon.2018.e00955

Shirwaikar, A., Rajendran, K., Punitha I. (2006): In vitro antioxidant studies on the benzyl tetra isoquinoline alkaloid berberine. Biol Pharm Bull 29: 1906-1910.

Singleton, V., Orthofer, R., Lamuela-Raventós, R. (1999) Analysis of total phenols and other oxidation substrates and antioxidants by means of folin-ciocalteu reagent. Methods in Enzymology 299: 152-178. https://doi.org/10.1016/S0076-6879(99)99017-1

Soetan, K., Olaiya, C., Oyewole, O. (2009): The importance of mineral elements for humans, domestic animals and plants: A review. African Journal of Food Science 4: 200-222.

Srivastava, P., Prasad, S., Ali, M., Prasad, M. (2015): Analysis of antioxidant activity of herbal yoghurt prepared from different milk. The Pharma Innovation Journal 4: 18-20.

Tamang, J., Shin, D., Jung, S., Chae S. (2016): Functional Properties of Microorganisms in Fermented Foods. Frontiers in microbiology 7: 578-578. 10.3389/fmicb.2016.00578

Tavakoli, M., Habibi Najafi, M., Mohebbi, M. (2019): Effect of the milk fat content and starter culture selection on proteolysis and antioxidant activity of probiotic yogurt. Heliyon 5: e01204-e01204. 10.1016/j.heliyon.2019.e01204 
Tomovska, J., Gjorgievski N., Makarijoski, B. (2016). Examination of pH, Titratable Acidity and Antioxidant Activity in Fermented Milk. Journal of Materials Science and Engineering 6: 326-333. doi: 10.17265/2161$6213 / 2016.11-12.006$

Wibawanti, M., Rinawidiastuti, Arifin, D., Zulfanita. (2018) Improving characteristics of goat milk yogurt drink fortified by mangosteen rind ( Garcinia mangostana Lin .) extract. IOP Conference Series: Earth and Environmental Science 102: 10.1088/1755-1315/102/1/012008.

Zhishen, J., Mengcheng, T., Jianming, W. (1999) The determination of flavonoid contents in mulberry and their scavenging effects on superoxide radicals. Food Chemistry 64: 555-559.

https://doi.org/10.1016/S0308-8146(98)00102-2

\section{Figures}



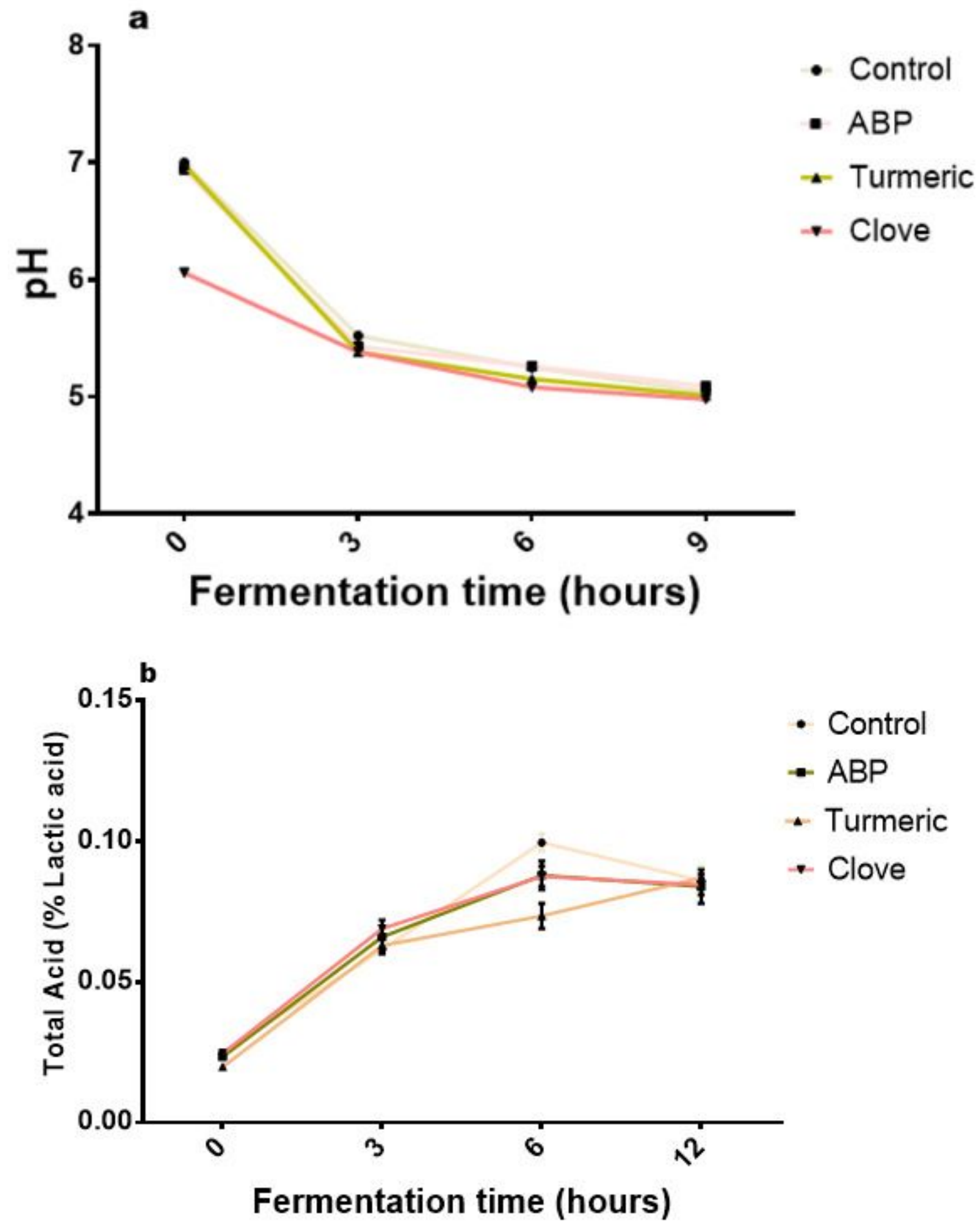

Figure 1

Effects of spices extracts on $\mathrm{pH}$ reduction (a), and total acid accumulation (b), of milk during fermentation. 

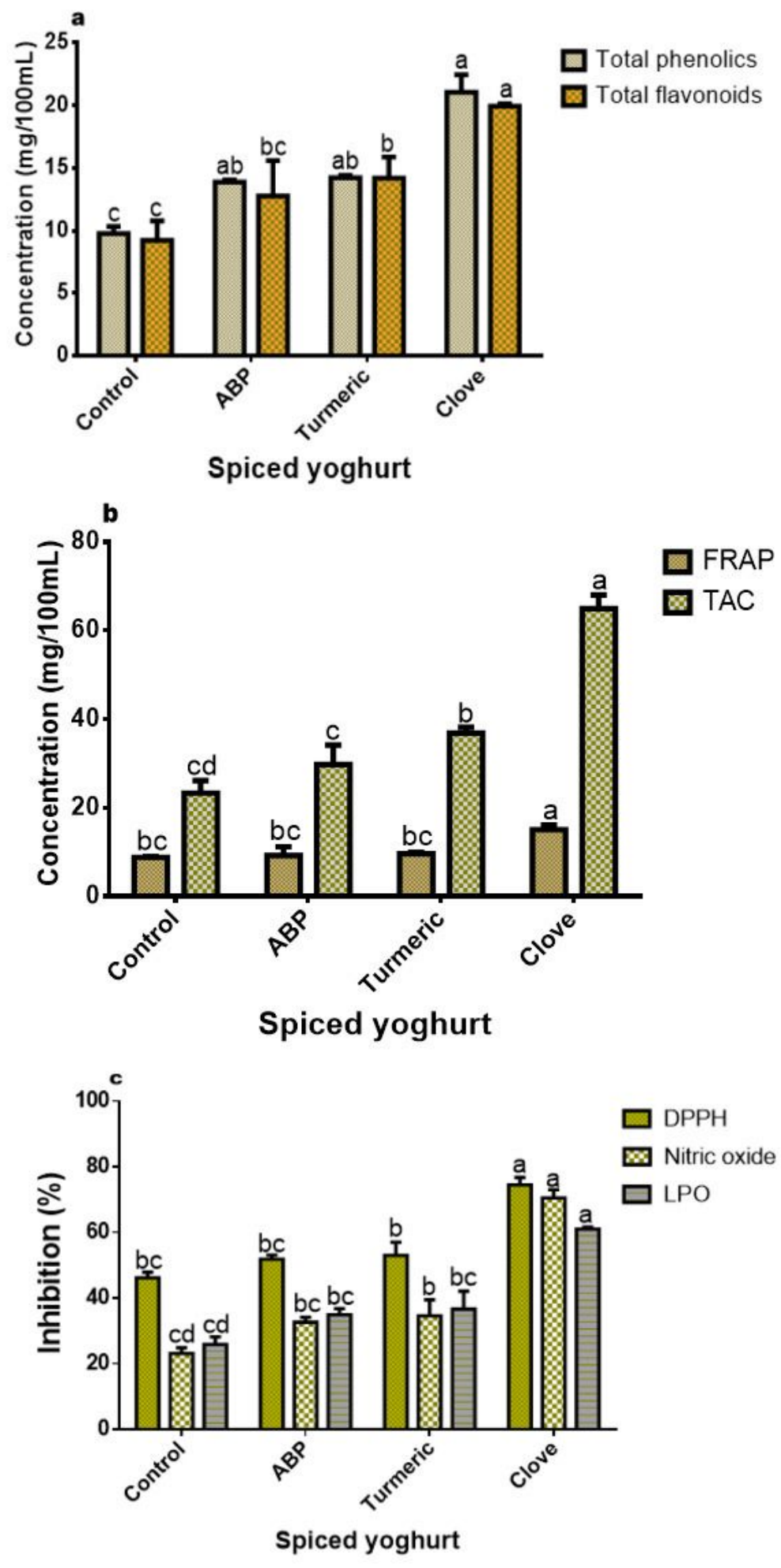

Figure 2

Antioxidant potentials of spiced yoghurt; Means of rank of classification of yoghurt samples are represented in alphabets; values with the same letter in the same column are not significantly different $(P>0.05)$. (a) total phenolic and total flavonoid contents (b) Ferric reducing antioxidant capacity (FRAP), total antioxidant capacity (TAC). (c) DPPH radical scavenging activity, Nitric oxide scavenging activity and lipid peroxidation. $\mathrm{ABP}=$ African Black Pepper. 


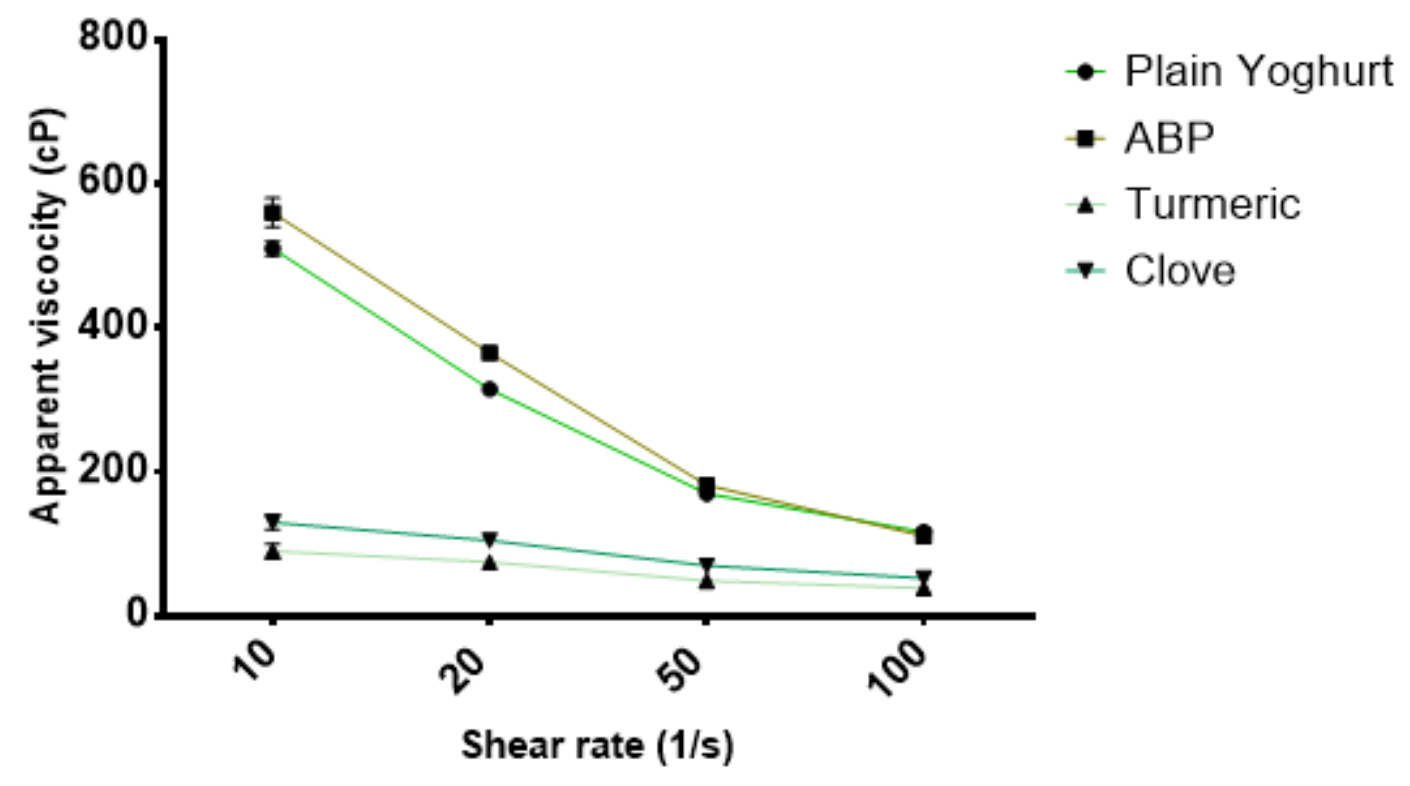

Figure 3

Apparent viscosity of yoghurt samples measured in centipoises (cP).

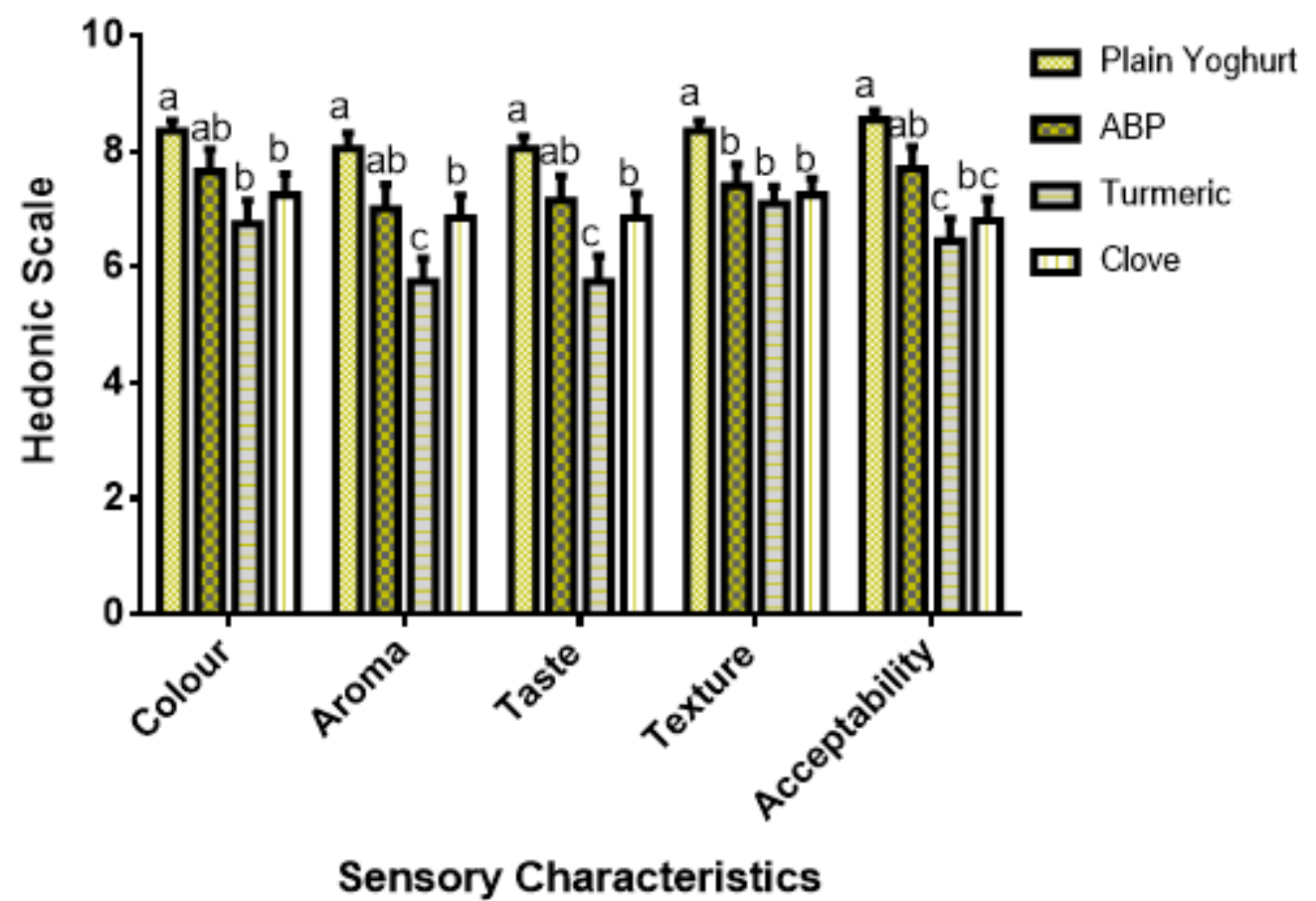

Figure 4

Sensory characteristics of spiced yoghurt samples. Means of rank of classification of yoghurt samples are represented in alphabets; values with the same letter in the same column are not significantly different $(P>0.05)$. 